\title{
Fluid Flow and Mass Flux Determinations at Vent Sites on the Cascadia Margin Accretionary Prism
}

\author{
BOBB CARSON
}

Department of Geological Sciences, Lehigh University, Bethlehem, Pennsylvania

ERWIN SLESS ${ }^{1}$

College of Oceanography, Oregon State University, Corvallis

\author{
JEFFREY C. STRASSER
}

Department of Geological Sciences, Lehigh University, Bethlehem, Pennsylvania

\begin{abstract}
Fluid venting from the toe of the accretionary prism off Oregon was measured in situ during a series of dives with DSRV Alvin in 1987 and 1988. A benthic chamber was placed over active vent sites to sequentially collect samples of venting fluids and to make direct measurements of discharge rates. Calibrated flow meter mea surements and flow rates determined from dissolved methane transfer indicate that discharge from two vent sites, Alvin 1428 and Alvin 1900, ranges roughly between 100 and $500 \mathrm{~L} \mathrm{~m}^{-2} \mathrm{~d}^{-1}$. with the most reliable estimates falling in the range of $125-150 \mathrm{~L} \mathrm{~m}^{-2} \mathrm{~d}^{-1}$. These rates imply subsurface advective flow on the order of $100 \mathrm{~m} \mathrm{yr}^{-1}$. Comparison of observed discharge rates with rates calculated for steady state expulsion supported by accretion-related compaction indicates that the observed flow is greater than predicted flow by several orders of magnitude. The disparity dictates that fluids are not derived locally, but are transported laterally within the prism, or that flow is not steady state and that individual vents are short-lived features in the ongoing accretion process.
\end{abstract}

\section{INTRODUCTION}

Indirect evidence for active expulsion of fluids at convergent margins has been suggested by the discovery of biological communities [Suess et al., 1985; Le Pichon et al., 1987] and diagenetic carbonate deposits at discrete vent sites [Ritger et al., 1987]. These sites are characterized by numerous clams (Calyptogena sp. and Solemya sp.), tube worms (Lamellibrachia barhami), secondary limestones which occur as subsurface concretions, outcropping beds, and free standing chimneys [Schroeder et al., 1987; Kulm and Suess, this issue], and pore fluids enriched in methane [Kulm et al., 1986; Boulègue et al., 1987; Suess and Whiticar, 1989]. This biological and geochemical evidence is taken to indicate advective transport of pore fluids to the sediment-water interface [Suess and Whiticar, 1989].

Although venting probably occurs across much of the Cascadia margin [Ritger et al., 1987], venting has been observed on the most western and youngest ridge of the lower continental slope (Figure 1). This anticlinal ridge (a fault-bend fold) lies above a landward-dipping thrust fault that separates sediments accreted to the North American plate from undeformed Cascadia Basin sediments on the Juan de Fuca plate [Moore et al., this issue]. The crest of the anticline trends nearly north-south and is broken

\footnotetext{
${ }^{1}$ Now at GEOMAR, Forschungszentrum für Marine Geowissenschaften, Kiel, Federal Republic of Germany.
}

\section{Copyright 1990 by the American Geophysical Union.}

Paper number 89JB 3276.

$0148-0227 / 90 / 89 \mathrm{JB}-03276 \$ 05.00$ by a topographic saddle that separates a submarine canyon to the west from nearly flat-lying, late Pleistocene deposits to the east. These horizontal turbidites were apparently ponded against the ridge during and subsequent to its uplift. The vent sites, Alvin 1428 and Alvin 1900 (named for the Alvin dives on which they were discovered), lie on the northern and southern boundaries of the saddle (Figure 1), in a transition zone between the flat-lying $\left(<10^{\circ}\right)$ turbidites and significantly steeper slopes $\left(20^{\circ}-40^{\circ}\right)$ of the ridge. Location of the vents has been attributed to fault control [Moore et al., this issue] or to the position of an unconformity between the underlying deformed deposits and the ponded sediments [Lewis and Cochrane, this issuc].

In a series of DSRV Alvin dives to these vent sites in 1987 and 1988, we made measurements of fluid discharge rates and transfer of dissolved methane from the sediments to the water column. A benthic chamber was used to collect sequential samples of venting fluids and to make direct determinations of flow rates. This device consists of an open-bottomed $28.8-\mathrm{cm}$ diameter $\left(0.26 \mathrm{~m}^{2}\right), 180-\mathrm{L}$ barrel with six 2-L Niskin bottles mounted inside. A $2.5-\mathrm{cm}$ exhaust port in the top of the barrel was designed to accept a Bernoulli-type flowmeter. In a typical deployment, the barrel was placed over an inferred site of active venting (as indicated by colonies of Calyptogena sp. clams in life position) using Alvin's hydraulic arm to seat the lower rim 3-6 cm below the sediment surface. The mechanism which trips the Niskin bottles was preprogrammed to close at specified intervals; it was timed so that ideally the first bottle closed before bottom deployment and thus sampled ambient bottom water. Subsequent bottles sampled increasing concentrations of fluids which escape from the seafloor, as the original water entrapped in the barrel was displaced and diluted by the fluids seeping into the barrel. After the sampling cycle was completed, a flowmeter was inserted in the exhaust port and read visually by an observer in 


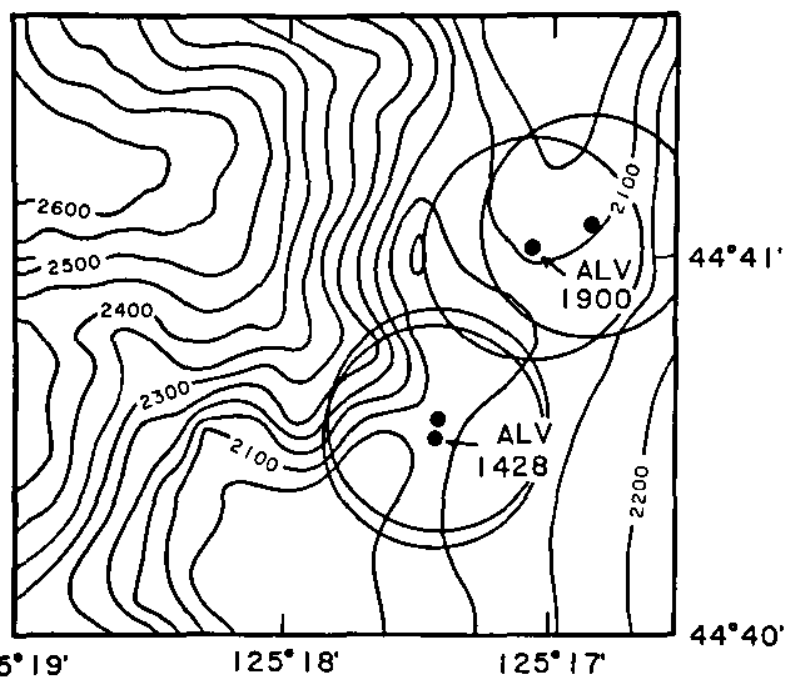

Fig. 1. Bathymetry of area studied and location of vent sites Alvin 1428 and $A$ lvin 1900. Unnumbered vents are inferred to be active as they, like 1428 and 1900, are characterized by authigenic carbonates, calyptogena sp. clarns, and Lamellibrachia barhami tube worm colonies. Circles indicate the source zone from which fluids would be drawn to an active vent $9 \mathrm{~m}^{2}$ in area under maximum compactive dewatering (see text) to support the observed discharge. Minimum compaction (see text) would require a source area, for each vent, larger than the total area outlined by the figure to support the observed discharge. Contour interval is $50 \mathrm{~m}$.

the submersible. Flowmeter readings were made at least $60 \mathrm{~min}$ after deployment, a ensuring pressure equilibration inside and out of the barrel [Cherkauer and McBride, 1988]. Design of the benthic barrel, technical details and deployment strategy are described by W.D. Rugh et al. (Determination of flow from a subduction vent, submitted to Deep-Sea Research, 1989).

Utilizing some of the results of these experiments, this paper (1) presents the physical measurements of fluid flow, (2) discusses calibration of the flowmeter, (3) demonstrates agreement between the physical measurements and estimates of fluid flow independently calculated from mass transport rates of methane, a short-term tracer, and (4) examines implications of the flow rates observed to initial prism dewatering. These data reflect the first-ever attempt to directly assess the venting rates at subduction zones. We realize that the estimates, which vary over time scales of hours to days, have errors associated with them, and that instrument design, sensitivity, and accuracy of flow measurements can all be considerably improved. Nevertheless, measured rates of fluid discharge and associated methane transport rates from accretionary prisms to the ocean are parameters of the highest significance to marine scientists and even order-of-magnitude estimates place important constraints on fluid flux associated with active accretion.

\section{Physical Measurement of Plum Flow}

\section{Flowmeter Calibration}

Compensation for three effects must be applied to the raw data to determine physical flow with the experimental apparatus described above: (1) the flowmeter reading must be corrected for variations in fluid viscosity induced by temperature, pressure, and salinity deviations from standard conditions; (2) backpressure, induced by forcing expelled fluids through the small flowmeter orifice, artificially reduces the observed flow; and (3) ambient flow past the barrel-flowmeter combination may induce a pressure gradient that serves to draw fluid out of the barrel. Adjustments for viscosity and backpressure effects have been applied to this experiment and are discussed below. The venturi effect was unanticipated and cannot be assessed quantitatively as no synoptic record of near-bottom current flow was made. However, this effect should be proportional to the ambient flow velocities and therefore becomes negligible at slack water, the condition at which our most reliable measurements were obtained. Tidal effects dominate the bottom water velocities, and the currents periodically drop to zero, which can be estimated from the submersible by the inclination of trajectories of settling suspensate. The flow measurements at Alvin 1428 were taken at slack water. At Alvin 1900, flow determinations were made under waning bottom current flow, and only very low flow rates $\left(<0.001 \mathrm{~mL} \mathrm{~min}^{-1}\right)$ were observed at slack water.

The flowmeter employed at both sites was a Gilson Instruments F-1100, nominally capable of measuring water flow between 0.005 and $4.0 \mathrm{~mL} \min ^{-1}$ at $21^{\circ} \mathrm{C}$ and $1.01 \times 10^{5} \mathrm{~Pa}$. Under ambient conditions (temperature $=1.7^{\circ} \mathrm{C}$, salinity $=34 \%$, pressure $=2.1 \times 10^{\circ} \mathrm{Pa}$ ), comparable readings correlate to flows ranging from 0.001 to $3.11 \mathrm{~mL} \mathrm{~min}^{-1}$ (Figure 2), based on algorithms supplied by the manufacturer. The deviation results from increased viscosity of the fluid in situ as compared with fresh water at standard temperature and pressure.

A much larger factor must be applied for induced backpressure. Seepage meters, of which the benthic barrel is a variation, are known to induce backpressures which reduce the collection efficiency [Bouwer and Rice, 1963; Woessner and Sullivan, 1984; Cherkauer and McBride, 1988]. The induced pressure field perturbates flow in the sediment column, so that some fluid is diverted and emanates outside the barrel's perimeter. This effect increases as the size of the exhaust port is reduced, and is considerable when the flowmeter is emplaced, for it has an inside diameter of $<1 \mathrm{~mm}$. (The effect is negligible when the flowmeter is not in place and the excurrent port has a diameter of $2.5 \mathrm{~cm}$ : the configuration during water sampling for methane transfer rates).

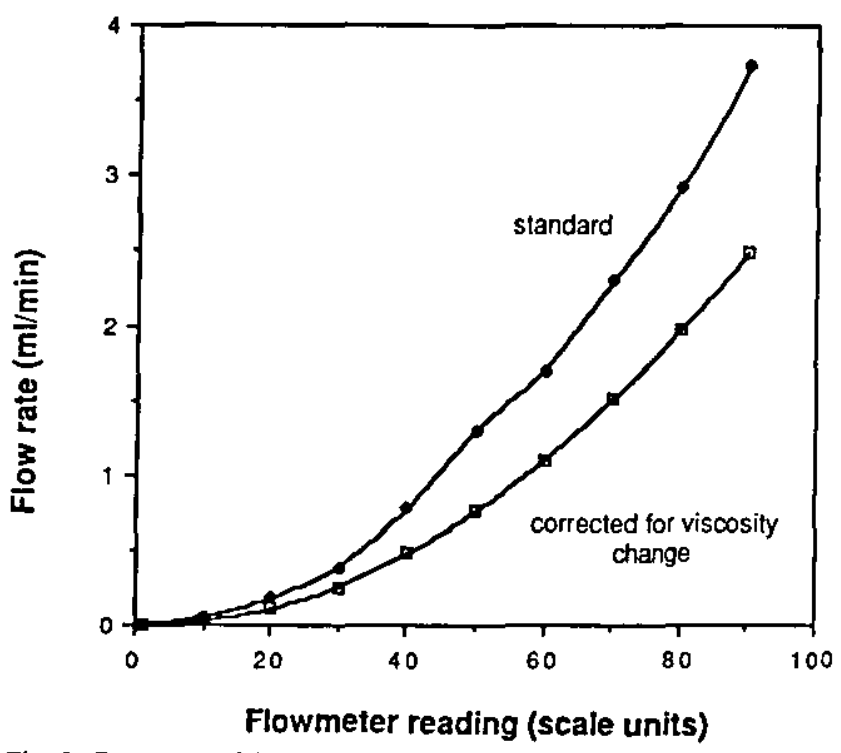

Fig. 2. Correction of flowmeter for in situ conditions $\left(T=1.7^{\circ} \mathrm{C}, S=\right.$ $\left.34 \%, \mathrm{P}=2.1 \times 10^{7} \mathrm{~Pa}\right)$ which affect fluid viscosity. Flow rate $\left(\mathrm{mL} \mathrm{min}^{-}\right.$ 1 ) is flow actually measured by flowmeter mounted on the benthic barrel. 
A calibration was performed using the apparatus diagrammed in Figure 3, to estimate the flow reduction due to backpressuring. A container $\left(53 \mathrm{~cm} \times 116 \mathrm{~cm} ; 0.62 \mathrm{~m}^{2}\right)$ was partially filled with sand to a depth of $60 \mathrm{~cm}$. A manifold of perforated plastic pipe was embedded $25 \mathrm{~cm}$ below the surface of the sand and connected through a Gilson F-1100 calibrated flowmeter (C, Figure 3) to a water source. A replica of the benthic bartel lid $\left(0.26 \mathrm{~m}^{2}\right)$, with another F-1100 flowmeter attached (C', Figure $3)$, covered $41 \%$ of the sand-water interface; the container was filled with water to a depth that immersed the top of the flowmeter. The sand consisted of well-sorted $\left(\sigma_{\phi}=0.33\right)$ very fine sand of mean grain size $2.81 \phi$ (moment measures).

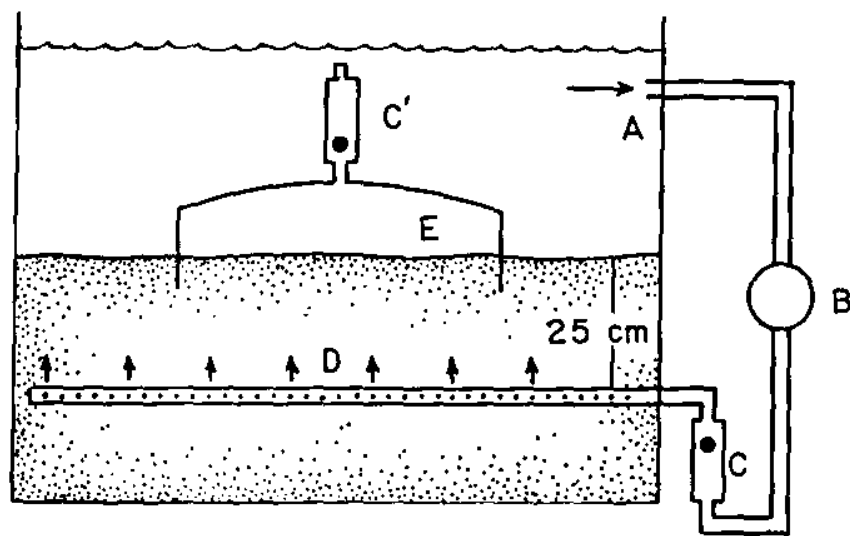

Fig. 3. Diagram of experimental apparatus used to account for backpressure effect on measured flow. Water is drawn from the upper portion of the tank (A) by an adjustable peristaltic pump (B) and forced through a flowmeter $(C)$ bcfore being introduced to the sediment in the tank by a manifold (D) consisting of four 1.9 -cm diameter, perforated pipes positioned $17.5 \mathrm{~cm}$ apart and buried $25 \mathrm{~cm}$ below the sediment surface. Flow from the manifold may bypass, or enter, the benthic chamber (E). Flow through the chamber is monitored by flowmeter $C$, which was identical to, and intercalibrated with, flowmeter $C$.

The calibration consisted of measuring the total inflow $(q)$ at flowmeter $\mathrm{C}$, calculating the resulting flux across the sediment surface $\left(q / 0.62 \mathrm{~m}^{2}\right)$, and comparing that flux with the observed flow through the lid-mounted flowmeter $\left(q^{\prime}\right)$. The results (Figure 4) indicate a significant linear relationship:

$$
y=126.6+207.2 x
$$

where $y$ is the actual flux through the sediment water interface $\left(\mathrm{mL} \min ^{-1} \mathrm{~m}^{-2}\right)=q / 0.62 \mathrm{~m}^{2}$ (see text) and $x$ is the flow rate measured at the barrel $\left(\mathrm{mL} \mathrm{min}^{-1}\right)=q^{\prime}$ (see text).

At the low flow rates examined, less than $0.1 \%$ of the actual flux through the sediment-water interface is intercepted by the barrel lid placed on the sediment surface. This efficiency is far lower than the $50-60 \%$ efficiency commonly attained by seepage meters [Cherkauer and $M c B r i d e, 1988$ ] and reflects the extremely small flowmeter orifice $(>1 \mathrm{~mm})$ relative to the area of the lid. The small orifice was required to record flow in real time, since the barrel had to be deployed and retrieved on a single dive for the chemical analyses. Nevertheless, replication during calibration indicates that the flowmeter test results are reproducible and that regression is significant at the $99 \%$ confidence level $(r=0.9958 ; n=8)$.

The calibration is valid, however, only for sediment which approximates the permeability of the test sand $\left(8 \times 10^{-4} \mathrm{~cm} \mathrm{~s}^{-1}\right.$, as

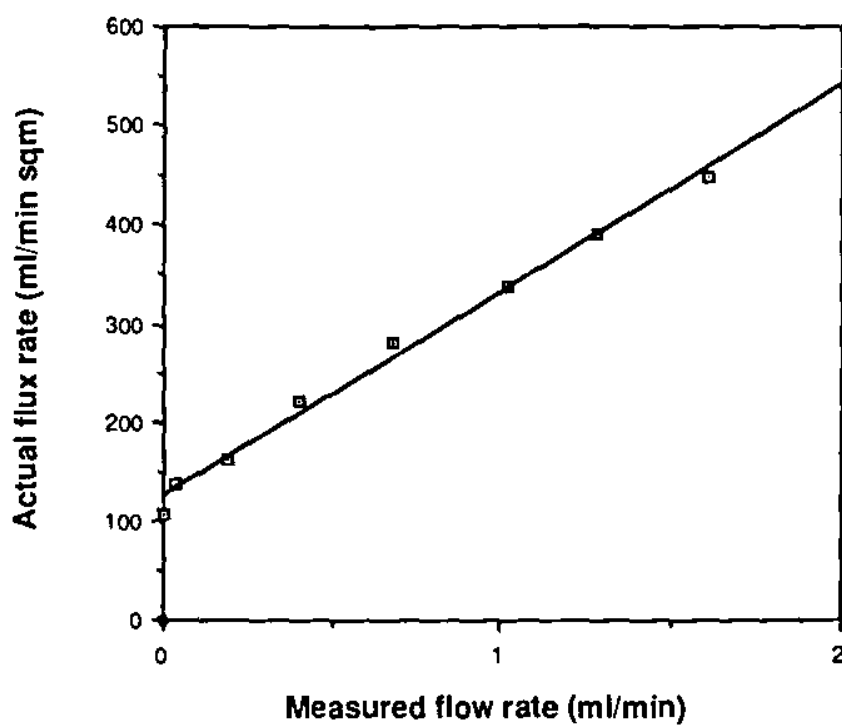

Fig. 4. Relation between flow races measured by flowmeter on barrel (mL min-1, $q^{\prime}$, see text) and actual flux through the sediment-water interface $\left(\mathrm{mL} \mathrm{m} \mathrm{min}^{-1}, q / 0.62 \mathrm{~m}^{2}\right.$, see text). Experimental points derived fran the apparatus diagrammed in Figure 3.

determined by a falling head test). Although sediment composition at the vent areas is somewhat variable, box cores collected at specific locations of active expulsion (as defined by high concentrations of live clams) invariably consist of fine, silty sand (>90\% sand; Alvin 1900: $90 \%$ sand, $0-7 \mathrm{~cm}$ subbottom; $96 \%$ sand, $114-20 \mathrm{~cm}$ subbottom). These deposits closely approximate the texture of the calibration sand. No hydraulic conductivity data of the vent site sediment are available, however, as we were unable in several attempts to collect an undisturbed box core. If the silt and clay fraction in the natural sediments (5-10\%) significantly reduce the hydraulic conductivity, less fluid would be diverted around the barrel, the efficiency would be higher than that claimed here $(<0.1 \%)$, and our flowmeter results reported below would overestimate actual flow somewhat.

\section{Flowmeter Results}

At Alvin 1428, flow through the barrel was steady at an uncorrected rate of $0.022 \mathrm{~mL} \mathrm{~min}^{-1}\left(0.085 \mathrm{~mL} \mathrm{~m}^{-2} \mathrm{~min}^{-1}=0.115\right.$ $\mathrm{L} \mathrm{m} \mathrm{m}^{-2} \mathrm{~d}^{-1)}$. The reading remained constant over a $10-\mathrm{min}$ period under negligible bottom current conditions. Corrected, steady

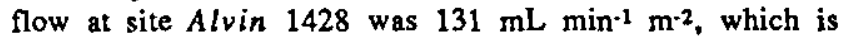
equivalent to $189 \mathrm{~L} \mathrm{~m}^{-2} \mathrm{~d}^{-1}(95 \%$ confidence interval about regression equation $\left.(1)=129-248 \mathrm{~L} \mathrm{~m}^{-2} \mathrm{~d}^{-1}\right)$.

In contrast, flow was variable at Alvin 1900 during dive 2052 , ranging from undetectable rates $\left(<0.001 \mathrm{~mL} \mathrm{~min}^{-1}\right)$ to $0.16 \mathrm{~mL}$ $\mathrm{min}^{-1}\left(<0.004-0.61 \mathrm{~mL} \mathrm{~m} \mathrm{~min}^{-1}=<0.01-0.88 \mathrm{~L} \mathrm{~m}^{-2} \mathrm{~d}^{-1}\right.$. uncorrected values) over separate 5- and $30-\mathrm{min}$ deployments. Generally, corrected flow rates declined (from $230 \mathrm{~L} \mathrm{~m}^{-2} \mathrm{~d}^{-1}$ to undetectable levels $\left(<127 \mathrm{~L} \mathrm{~m}^{-2} \mathrm{~d}^{-1}\right)$ ) over the duration of the experiment. Although no external current meter was available to record the near-bottom currents, a general correlation was apparent between the ambient current velocity (as estimated by the inclination of suspensate trajectories) and the discharge rates recorded by the barrel-mounted flowmeter. This correlation suggests that a venturi effect caused by diversion of flow around the barrel or flowmeter may have contributed to the readings under non-slack-water conditions. Under slack conditions, flow 
can only be said to be less than $127 \mathrm{~L} \mathrm{~m}^{-2} \mathrm{~d}^{-1}$. Alternatively, we cannot rule out the possibility that venting is a temporally variable process and that the data reflect natural fluctuations in the flux.

\section{FLow RATES DETERMNED From MASS TRANSFER OF METIIANE}

Dissolved methane is a major chemical component of fluids escaping from both vent sites Alvin 1428 and Alvin 1900. In the oxic bottom water and the sulfate-containing subsurface, methane is a tracer for fluid flow because its existence or generation is incompatible with the diagenetic reactions of these environments [Claypool and Kaplan, 1974]. Instead methane is generated from reduction of dissolved carbonate by microbes at greater depths, below the sulfate reduction zone. Methane is carried upward by fluids through the sediment water interface and injected into the bottom water where it supports a large and unique community of benthic biota.

At Alvin 1428 the maximum (and mean, in parentheses) rate of methane transport from the seafloor was $10.3(9.1) \mathrm{mmol} \mathrm{m}^{-2}$ $\mathrm{d}^{-1}$. At Alvin 1900, two deployments of the instrument, three days apart, yielded greatly different methane flux rates from the same spot: $85.1(83.5) \mathrm{mmol} \mathrm{m}^{-2} \mathrm{~d}^{-1}$ were first measured during dive 2046 (Figure $5 a$ ) and $14.7(13.9) \mathrm{mmol} \mathrm{m}^{-2} \mathrm{~d}^{-1}$ later during dive 2049 (Figure $5 b$ ). The signification variation lends credence to the (flowmeter-based) observation that fluid flux may be highly variable at this site. Flux estimates are based on the increase in dissolved $\mathrm{CH}_{4}$ concentration in the bottom water which was enclosed by the benthic barrel for the respective deployment times. The increase in methane concentrations (in $\mu \mathrm{mol} \mathrm{L}-1)$ with time $\left(\mu \mathrm{M} \mathrm{min}^{-1}\right)$ is converted to total methane flux by multiplying it by the volume enclosed by the barrel $(180 \mathrm{~L})$ and divided by the area covered by the barrel $\left(0.26 \mathrm{~m}^{2}\right)$.

During dive 2046, the increase in methane concentration appeared linear with one measurement at the end of the deployment showing lower concentrations than expected from extrapolation. The methane contents sampled in the last bottle were unexpectedly high so that the detection system of the gas chromatograph became overloaded; therefore, the last point represents a minimum concentration and is not included in the calculation of the maximum flux rates. However, the mean flux rate of methane is based on all of the measured concentrations. Difficulty in locating vent Alvin 1900 during dive 2046 delayed barrel deployment sufficiently long that the first and second bottles tripped before the barrel was in place. Accordingly, two data points are plotted at time 0 (Figure 5a).

The opposite was the case three days later during deployment on dive 2049. This time the vent was quickly located and the barrel positioned in place $30 \mathrm{~min}$ ahead of closure of the first bottle. For that reason there are six data points plotted in Figure $5 b$ beyond time 0 . Of these, the third data point (vertical arrow) contained so much methane that the gas chromatographic (GC) detection system became overloaded. This problem was eliminated during subsequent samples $(4,5,6)$ by switching to smaller sample cells and hence lesser amounts of methane. Again, as with dive 2046, this minimum value (sample 3 ) was not included in the regression calculation of the total methane flux.

The water flow at Alvin 1428 was physically measured following the sampling of the barrel water for dissolved methane. At Alvin 1900 this was not the case because of malfunction of the flowmeters during dives 2046 and 2049. However, when the flowmeter finally yielded good results during dive 2052, as
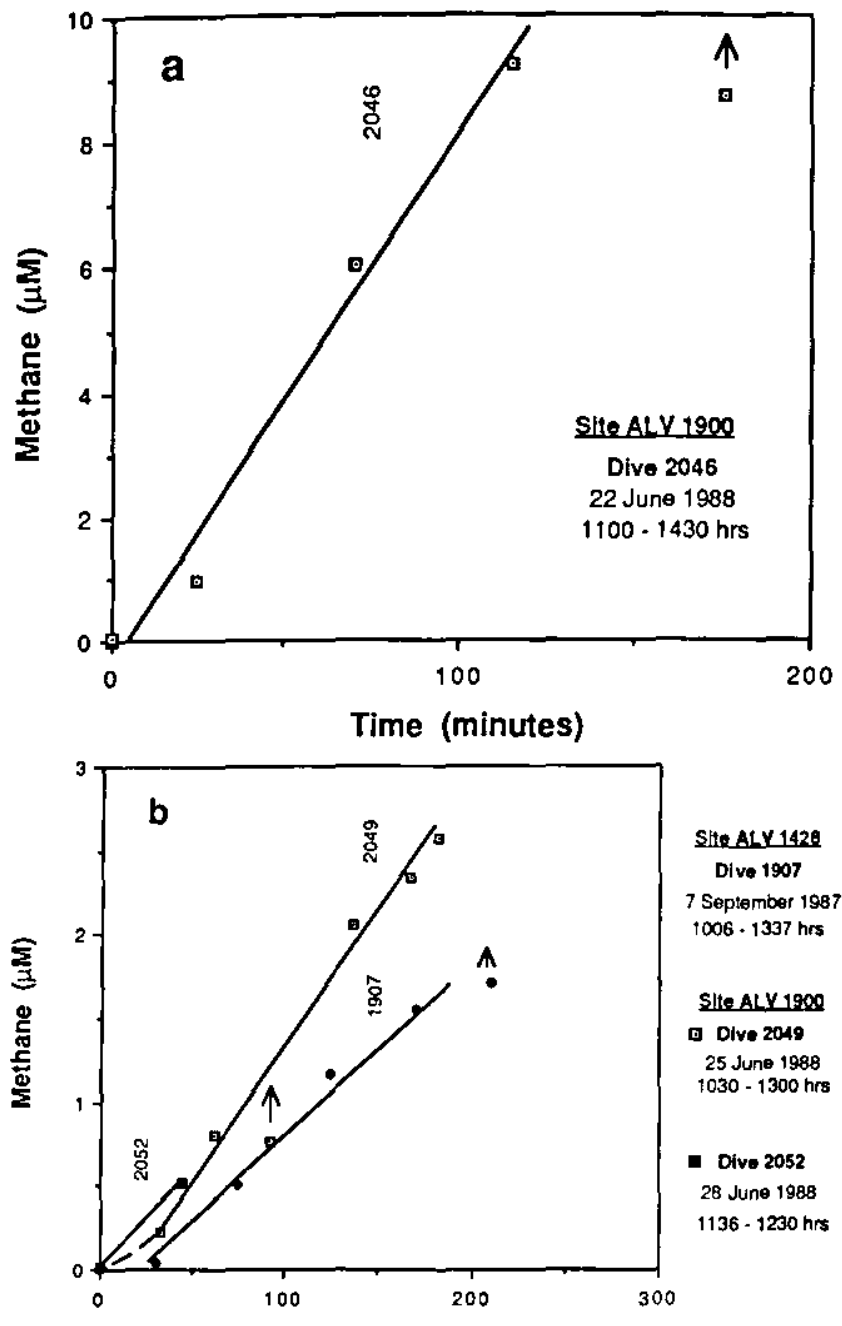

Time (minutes)

Fig. 5. Change in methane content of bottom water enclosed by the Benthic Bamel at vent sites Alvin 1428 and Alvin 1900. (a) DSRV Alvin dive 2046 and $(b) A l v i n$ dives 1907. 2049, and 2052. During the deployment at dive 2046 the methane injection into the benthic bartel at the same spot was 3 times higher than during later dives 2049 and 2052. $\mu \mathrm{M}=\mu \mathrm{mol} \mathrm{L}-1$.

discussed in the preceding section, two determinations of methane concentration were made at that location only $44 \mathrm{~min}$ apart. They agree quite well with those observed over the duration of the previous dive 2049 (Figure $5 b$ ); therefore the physical flow rates should be assessed only in the context of the methane flux rates determined for deployment 2049/2052, and not relative to the very high rate measured during dive 2046.

In an attempt to estimate water flow from methane flux rates, we assume, as a first approximation, that methane behaves conservatively during the period of deployment, i.e., it is neither measurably consumed nor generated by the vent biota over approximately $50-200 \mathrm{~min}$. Therefore, if the methane content in the pore fluids feeding the vent is known, the water flow is simply calculated from the total quantity of methane injected into the barrel divided by the concentration of methane in the feed water in the sediment (Table 1). At Alvin 1428 the total methane was $19.6 \mu \mathrm{mol} / \mathrm{kg}$ of wet sediment. At Alvin 1900 we have several measurements of methane in surface sediments from the vicinity of the vent which range from 15.0 to $49.7 \mu \mathrm{mol} / \mathrm{kg}$. All samples are from within the sulfate-containing zone not deeper 
than $20 \mathrm{~cm}$ below seafloor. The methane contents include 3.6 $\mu \mathrm{mol}$ of sorbed methane per kilogram of wet sediment [Whiticar and Faber, 1988]. This fraction is not capable of freely moving with the vent water and has to be subtracted. After converting the concentrations of methane from Hmoles per weight of wet sediment to $\mu$ moles per volume of pore fluid (using the water content of sediment at Alvin 1428 which was $21.5 \%$ weight percent) we estimate that methane in the feed water at Alvin 1428 was $66 \mu \mathrm{mol} / \mathrm{L}$ and at Alvin 1900 between 30 and $150 \mu \mathrm{mol} / \mathrm{L}$. The methane flux rates yield water flow rates (Table 1) of $156 \mathrm{~L}$ $\mathrm{m}^{-2} \mathrm{~d}^{-1}$ for site Alvin 1428 and $98-490 \mathrm{~L} \mathrm{~m}^{-2} \mathrm{~d}^{-1}$ (mean $223 \mathrm{~L} \mathrm{~m}^{-2}$ $d^{-1}$ ) for Alvin 1900.

\section{DISCUSSION}

The flow rates determined in these experiments, which range from about 100 and $500 \mathrm{~L} \mathrm{~m}^{-2} \mathrm{~d}^{-1}$, are very high considering that the fluids are derived from compactive dewatering of the sediments [Carson, 1977; Han and Suess, 1989]. Nevertheless, the agreement between independent physically and chemically derived flow estimates is acceptable and suggests that the flux rates are realistic.

This is not to say, however, that the discharge rates should be accepted unequivocally nor that they persist continuously over long periods of time. The chemically derived rates are not corrected for backpressuring (which is considerably lower with the $2.5-\mathrm{cm}$ exhaust port than when the flowmeter with $<1-\mathrm{mm}$ opening is emplaced), nor for possible methane consumption during barrel deployment. The uncertainty in methane content of the subsurface feed water is also large, as shown by the data. Furthermore, the backpressure calibration is dependent upon the hydraulic conductivity of the sediment, and we have no reliable estimate of the in situ conductivity, largely because clams, carbonate concretions, and the noncohesive nature of the vent sediments have precluded obtaining an undisturbed sample of appropriate dimensions. We judge, however, that these effects are relatively minor and that the expulsion rates published here are at least correct to an order of magnitude.

The measured flow rates dictate that subsurface flow is advective. A mean discharge rate of $185 \mathrm{~L} \mathrm{~m}^{-2} \mathrm{~d}^{-1}$ requires vertical advection at rates ranging from $85-170 \mathrm{~m} \mathrm{yr}^{-1}$, depending upon the porosity of the underlying sediments (Figure 6). Evaluation of the porosity determined from returned samples at Deep Sea Drilling Project (DSDP) site 175 (located $15 \mathrm{~km}$ north of Alvin 1900 [Carson, 1977]) suggests an average porosity of $55-60 \%$ in the upper $100 \mathrm{~m}$ of the sediment column, which would imply rates of vertical advection between 105 and $115 \mathrm{~m} \mathrm{yr}^{-1}$. Clearly this rate results from a concentration of flow along

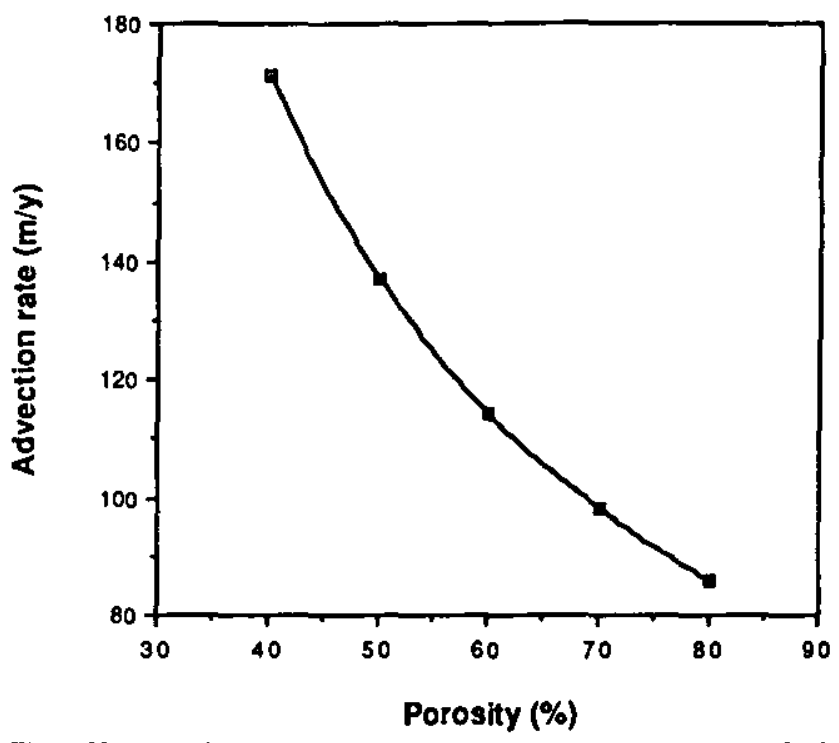

Fig. 6. Vertical advection rates required to support a flow of $185 \mathrm{~L} \mathrm{~m}^{-2} \mathrm{~d}^{-1}$, depending upon subsurface poros ities.

restricted aquifers, probably either fault zones or stratigraphic units of high hydraulic conductivity.

These high flow rates, however, complicate and constrain water release associated with prism accretion. Compressional seismic wave velocities indicate that the upper 100 meters below seafloor (mbsf) beneath the ridge on which the vents occur has an average porosity 5-13\% lower than comparable sediment in adjacent Cascadia Basin. Porosities below 100 mbsf are, however, greater beneath the ridge than in the undeformed sediments of the basin, suggesting that the strata below $100 \mathrm{mbsf}$ are not actively dewatering and cannot be the source of the venting fluids [Strasser ef al., 1989]. The lack of thermogenic methane in pore waters [Suess and Whiticar, 1989] supports the conclusion that fluids are not derived from great depth, but only constrains their source to less than 750 mbsf [Ritger et al., 1987]. The porosity decrease in the upper $100 \mathrm{mbsf}$, which is the most obvious and immediate source of fluids, may result from tectonic dewatering at the toe of the prism or from exhumation of previously buried and compacted strata, but probably only the former phenomenon could cause dewatering after accretion.

It is possible to predict maximum and minimum rates of expulsion caused by tectonically induced porosity reduction and simple upward advection of fluids, assuming steady state discharge. If all venting fluids originate above $100 \mathrm{mbsf}$, a $1 \mathrm{~m} \times$ $1 \mathrm{~m} \times 100 \mathrm{~m}$ control volume can be used to determine the fluid

TABLE 1. Comparison Between Measured (Flowmeter) Fluid Flow and Estimated Fluid Flow Using Dissolved Methane Fluxes

\begin{tabular}{|c|c|c|c|c|c|c|}
\hline $\begin{array}{l}\text { Vent } \\
\text { Alvin }\end{array}$ & Dive & Date & $\begin{array}{l}\text { Methane Flux, } \\
\text { mmol m-2 } \mathrm{d}^{-1}\end{array}$ & $\begin{array}{l}\text { Feed Water } \\
\text { Methane, } \\
\mu \mathrm{mol} \mathrm{L}\end{array}$ & $\begin{array}{l}\text { Estimated } \\
\text { Fluid Flow, } \\
\mathrm{L} \mathrm{m}^{-2} \mathrm{~d}^{-1}\end{array}$ & $\begin{array}{l}\text { Measured } \\
\text { Fluid Flow, } \\
\mathrm{L} \mathrm{m}^{-2} \mathrm{~d}^{-1}\end{array}$ \\
\hline 1428 & 1907 & Sept. 7, 1987 & 10.3 & 66 & 156 & 188 \\
\hline 1900 & $\begin{array}{l}2046 \\
2049 \\
2052\end{array}$ & $\begin{array}{l}\text { June } 22,1988 \\
\text { June } 25,1988 \\
\text { June } 28,1988\end{array}$ & $\begin{array}{l}85.1 \\
14.7 \\
14.7\end{array}$ & $\begin{array}{c}\text { n.2. } \\
30-150 \\
30-150\end{array}$ & $\begin{array}{c}\text { n.a. } \\
98-490 \\
98-490\end{array}$ & $\begin{array}{c}\text { n.d. } \\
\text { n.d. } \\
<127-230\end{array}$ \\
\hline
\end{tabular}


inventory. A $13 \%$ reduction in average porosity in the control volume as it is accreted results in the expulsion of $13 \mathrm{~m}^{3}$ of interstitial fluid. If the tectonic activity which induced this porosity reduction was uplift of the marginal ridge, the time over which dewatering has occurred is constrained by the age of the ridge. A minimum age of $20 \mathrm{kyr}$ for the ridge uplift implies a maximum dewatering rate of $1.8 \times 10-6 \mathrm{~m}^{3} \mathrm{~m}^{-2} \mathrm{~d}^{-1}$, whereas the measured venting is $1.8 \times 10^{-1} \mathrm{~m}^{3} \mathrm{~m}^{-2} \mathrm{~d}^{-1}$. A typical vent, as observed from DSRV Alvin is roughly $9 \mathrm{~m}^{2}$, out of which the flow is calculated to be $1.6 \mathrm{~m}^{3} \mathrm{~d}^{-1}$. Under the conditions assumed for maximum discharge (13\% porosity reduction over $20 \mathrm{kyr}$ ), this rate of flow can be accounted for only if the vent discharges fluids from the sediments beneath an area of approximately $9.0 \times$ $10^{5} \mathrm{~m}^{2}$ (Figure 1). Altematively, a porosity decrease of only $5 \%$ in the top $100 \mathrm{~m}$ of the sediment column, causing expulsion of only $5 \mathrm{~m}^{3}$ of fluids from each $100-\mathrm{m}^{3}$ control volume, coupled with a more realistic age of $300 \mathrm{kyr}$ for the uplifted ridge [Kulm et al., 1973], implies a minimum expulsion rate of $4.6 \times 10^{-8} \mathrm{~m}^{3}$ $\mathrm{m}^{-2} \mathrm{~d}^{-1}$. To account for the measured discharge $\left(1.8 \times 10^{-1} \mathrm{~m}^{3}\right.$ $\left.\mathrm{m}^{-2} \mathrm{~d}^{-1}\right)$, each $9-\mathrm{m}^{2}$ vent must then draw fluids from beneath an area of roughly $4.0 \times 10^{7} \mathrm{~m}^{2}$. Both scenarios suggest that large sediment volumes $\left(10^{7}-10^{9} \mathrm{~m}^{3}\right)$ are required to support the observed flow, and that if vents are driven by steady state, compactive dewatering, they should be widely dispersed. The circles plotted on Figure 1, around each of the active vents discovered to date, indicate the surface trace of the hypothetical source zones, if a vent lies at the center of each zone. The significant overlap of the source zones suggests that the simple compaction model is invalid. Either vented fluids migrate from some distance to the site of expulsion, or flow is not steady state. Both conclusions are probably true. Fluid migration along faults [Moore et al, this issue] or stratigraphic aquifers [Lewis and Cochrane, this issue] is hypothesized, and discovery of relict as well as active vent sites [Moore et al., this issue] dictates that flow is temporally variable.

If dispersed discharge (as opposed to localized venting) is an important component of prism dewatering, the source water shortfall outlined above is exacerbated as some portion of the pore fluid would escape at nonvent locations. It may be that other sources of fluid contribute to the discharge reported in this study. Mineral dehydration, clathrate decomposition, or convective inflow of seawater to the sediment column may be sources that future hydrologic models must consider [von Huene et al., 1988; Suess et al., 1988].

\section{CONCLUSIONS}

Direct (flowmeter) and indirect (chemical mass flux) measurements were made of pore water discharge at vent sites on the Cascadia margin accretionary prism. A benthic chamber was placed over two active vents (Alvin 1428 and Alvin 1900) on the westernmost ridge of the lower continental slope off Oregon in water depths of $2050-2100 \mathrm{~m}$. At Alvin 1428, flow was steady at 156-188 $\mathrm{L} \mathrm{m}^{-2} \mathrm{~d}^{-1}$, while at Alvin 1900 , flow was more variable, ranging from $98-490 \mathrm{~L} \mathrm{~m}^{-2} \mathrm{~d}^{-1}$.

These are exceedingly high discharge rates which imply advective subsurface flow of approximately $100 \mathrm{~m} \mathrm{yr}^{-1}$. Such flow can be supported by compaction only if the vents discharge fluids derived from a large sediment volume $\left(10^{7}-10^{9} \mathrm{~m}^{3}\right)$ involved in accretion. Spacing of mapped vent sites, however, indicates that local pore water volumes are insufficient to support the observed rates of flow as steady state discharge. We conclude, therefore, that the vents must be fed by high hydraulic conductivity aquifers, either faults or stratigraphic horizons, which transport fluids laterally across at least some portion of the prism. This transport has to be reconciled, however, with the fact that both geochemical and geophysical data indicate that fluids are derived from shallow depths ( $<100-750 \mathrm{mbs})$ in the sediment column [Ritger et al, 1987; Suess and Whiticar, 1989; Strasser et al., 1989]. Alternatively, the observed discharge may indicate short-term, nonsteady flow, or contributions of fluids derived from mineral dehydration, clathrate decomposition, or seawater recharge. The marked disparity between observed flow and calculated discharge based on the assumption of steady state compactive dewatering suggests that these altematives require serious evaluation.

Acknowledgments. William Rugh designed and fabricated the benthic barrel. We wish to thank the pilots of the DSRV Alvin and crew of the Atlantis II for logistical support, advice, and skillful deployment and recovery of the experimental apparatus. Flowmeter calibration and permeability tests were performed in the Imbt Hydraulics Laboratory at Lehigh University with assistance from $R$. Weisman, G. Lennon, and C.T. Chang. Financial support for this project was provided by the National Science Foundation under grants OCE-8613501 and OCE8609789 .

\section{REFERENCES}

Boulègue, J., J.T. Liyama, J.-L. Charlou, and J. Jedwab, Nankai Trough. Japan Trench, and Kuril Trench: Geochemistry of fluids sampled by the submersible Nautile, Earth Planet. Sci. Lett., 83, 363-375, 1987.

Brouwer, H., and R.C. Rice, Seepage meters in seepage and recharge studies, J. Irrig. Drain. Div., Am. Soc. Civ. Eng., 89, 17-42, 1963.

Carson, B., Tectonically induced defomation of deep-sea sediments off Washington and northern Oregon: Mechanical consolidation, Mar. Geol., 24, 289-307, 1977.

Cherkauer, D.A., and J.M. McB ride, A remotely operated seepage meter for use in large lakes and rivers, Ground Water, 26(2), 165-171, 1988.

Claypool, G.E., and I.R. Kaplan. The origin and distribution of methane in marine sediments, in Natural Gases in Marine Sediments, edited by J.R. Kaplan, pp. 99-140, Plenum, New York, 1974.

Han, M.W, and E. Suess, Subduction-induced pore fluid venting and the fomation of authigenic carbonates along the Cascadia continental margin: Implications for the global Ca-cycle, Paleograph. Paleoclimatol. Paleoecol., 71, 97-118, 1989.

Kulm, L.D. and E. Suess, Relationship between cartonate deposits and fluid venting: Oregon accretionary prism, J. Geophys. Res., this issue.

Kulm, L.D., et al., Initial Rep. Deep Seo Drill Proj., 18, 1077 pp., 1973.

Kulm, L.D., et al., Oregon margin subduction zone: Geologic framework, fluid venting, biological communities, and carbonate lithification observed by deep submersible, Science, 231, 561-566, 1986.

Le Pichon, X., et al., Nankai Trough and Zenisu Ridge: A deep-sea submersible survey, Earth Planet. Sci. Lett., 83, 285-299, 1987.

Lewis, B.T.R., and G.C. Cochrane, Relationship between the location of chemosynthetic benthic communities and geologic structure on the Cascadia subduction zone, J. Geophys. Res., this issue.

Moore, J.C., D. Orange, and L.D. Kulm, Interrelationship of fluid venting and structural evolution : Alvin observations from the frontal accretionary prism, Oregon, J. Geophys. Res., this issue.

Ritger, S., B. Carson, and E. Suess, Methane-derived authigenic carbonates formed by subduction-induced pore-water expulsion along the Oregon/Washington margin, Geol. Soc. Am. Bull., 98, 147-156, 1987.

Schroeder, N.A.M., L.D. Kulm, and G.E. Muehlberg, Carbonate chimneys on the outer continental shelf: Evidence for fluid venting on the Oregon margin, Oreg. Geol., 49 (8), 91-96, 1987.

Strasser, J.C., B. Carson, and B.T.R. Lewis, Velocity-derived porosity distribution of the lower Oregon margin accretionary prism: Implications for dewatering, paper presented at National Meeting, St. Louis, Mo., Geol. Soc. of Am., Abstr. with Progr. 21, A312, 1989.

Suess, E., and M.J. Whiticar, Methane-derived $\mathrm{CO}_{2}$ in pore fluids expelled from the Oregon subduction zone, Paleogeogr. Paleoclimatol. Paleoecol., 71, 119-136, 1989.

Suess, E., B. Carson, S. Ritger, J.C. Moore, M.L. Jones, L.D. Kulm, and G.R. Cochrane. Biological communities at vent sites along the subduction zone off Oregon. The Hydrothermal Vents of the Eastem 
Pacific: An Overview, edited by M.L. Jones, Biol. Soc. Wash. Bull., $6,474-484,1985$.

Suess, E., R. von Huene, and Leg 112 Shipboard Scientists, Ocean Drilling Program Leg 112, Penu continental margin, Sedimentary history and diagenesis in a coastal upwelling environment, Geology, $16,939-943,1988$.

von Huene, R., E. Suess, and Leg 112 Shipboard Scientists, Ocean Drilling Program Leg 112, Peru continental margin, 1. Tectonic history, Geology, 16, 934-938, 1988.

Whiticar, M.J., and E. Faber, Carbon, hydrogen, and oxygen isotope distribution in the interstitial fluids of ODP Leg 104, Holes 642B, $643 \mathrm{~A}$, and 644A, Voring Plateau, Norwegian Sea. edited by $O$. Eldholm, J. Thiede and E. Taylor, Proc. Ocean Drill. Program Scientific Results, 104, 285-290, 1988.
Woessner, W.W., and K.E. Sullivan, Results of seepage meter and minipiezometer study, Lake Mead, Nevada, Ground Water, 22(5), 561 -568, 1984.

B. Carson and J.C. Strasser, Department of Geological Sciences, Lehigh University, Bethlehem, PA 18015.

E. Suess, College of Oceanography, Oregon State University, Corvallis, OR 97331.5503.

revised August 22,1989

accepted October $18,1989$. 